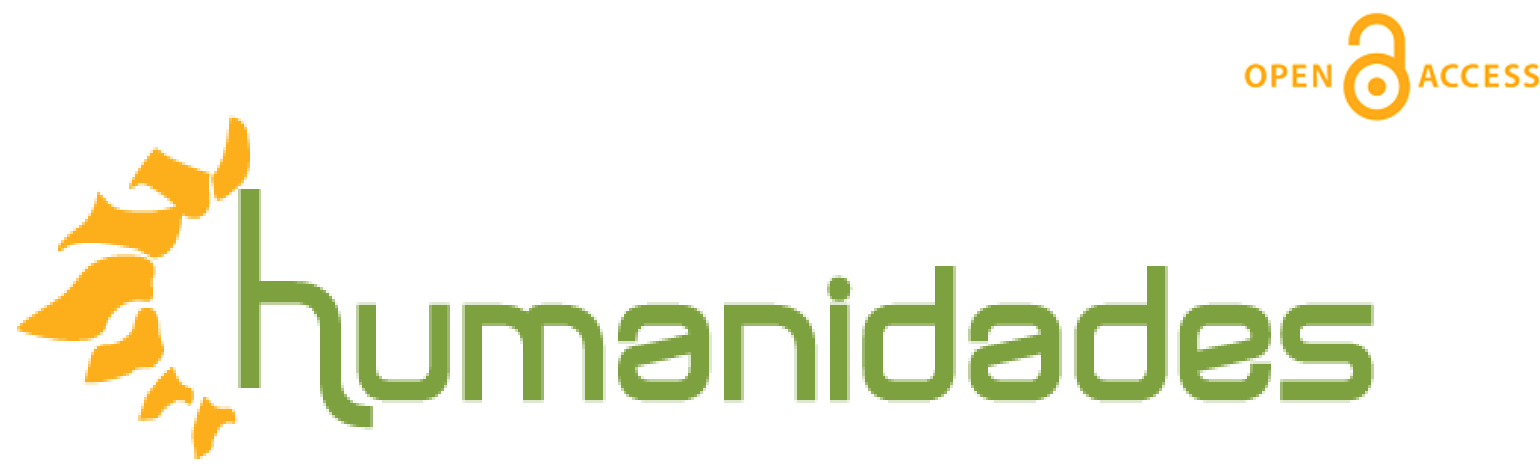

Revista de la Escuela de Estudios Generales, Universidad de Costa Rica

Julio-diciembre, 2016 • Volumen 6, número 2・EISSN 2215-3934 • pp. 1-6

\title{
Microrrelatos
}

DOI: http://dx.doi.org/10.15517/h.v6i2.26750

\section{Ronald Hernández Campos}

Bachiller en Filología Española y en Enseñanza del Castellano en la Universidad de Costa Rica, profesor de Español en el Ministerio de Educación Pública.

Correo electrónico: ronhc3110@gmail.com

Todos los derechos reservados. Universidad de Costa Rica. Esta revista se encuentra licenciada con Creative Commons. Reconocimiento-NoComercial-SinObraDerivada 3.0 Costa Rica.

Correo electrónico: humanidades@ucr.ac.cr / Sitio web: http://revistas.ucr.ac.cr/index.php/humanidades 


\section{Las fechas importantes}

... a Pedro Arias Matarrita.

Uno decide creer que hay fechas importantes en el calendario porque así es de ingrata la memoria. Un día, no recuerdo al propio el lugar de la casa en el que estábamos, mis tatas y yo conversábamos acerca de mi nacimiento, como de tantas fechas que se suponen importantes, como si traer carajillos al mundo lo fuera, aunque para mis tatas la planificación familiar era más compleja que criar los hijos que Dios quisiera enviarles.

— Todos fueron planeados, papito... — salió diciendo mi mama. Mi tata solo se limitó a medio sonreír y a ver hacia otra parte.

-Es curioso, creo que tiene razón, aunque yo no lo veo así: hay un lapso de nueve meses entre el cumple del mayor y el de papi; nueve meses entre el cumpleaños suyo y el de mi hermana; nueve meses entre navidad y el menor, y nueve meses entre el aniversario de ustedes y mi cumple.

Mi mama se había limitado a escuchar como pocas veces y mi tata a reírse.

— Las cosas no son así, usted está calculando mal — brincó mi mama.

- También está raro que en su cuarto hubiera una bolsa de condones, de los que da la Caja y al final nacimos cuatro...

—Es que eso no es de Dios... — concluyó rápidamente mi madre. Las fechas importantes sí habían calado hondo en la vida familiar, o en el sexo conyugal y la planificación familiar que manejaban mis tatas. 


\section{Las ventajas de ser invisible}

... a Orlando.

No tenía intenciones de que me conociera nadie. En realidad, nadie se me acercaba. Otro cole, el tercero. No sabía cómo hacer amigos en el cole. No lo intenté. Ellos llegaron solos, así se fueron también. No sabía cómo tener novia. NO lo intenté -ella llegó y se fue sola-, creo. Era el típico mae raro al que nadie le habla: me metía en mi mundo y ya, aunque la gente le parecía necesario entablar una conversación y a ella también.

— Hola — se acercó un día una chica, una de las más guapas del lugar.

- Hola — le contesté, apenas si la vi. Estaba sentado en una mesa jugando con el cel.

— ¿Por qué siempre estás solo, mae?

-Porque no conozco a nadie.

— ¿Y no me querés conocer a mí?

¿Para qué decirle que sí? Era obvio. La pregunta sobraba. No es que supiera cómo llegarle a una güila, es que al menos fingir indiferencia tuvo sus ventajas hasta ese instante. 


\section{Diálogos inútiles: Es lo mejor... para alguien más}

-Ya recogí todo.

-Me parece bien.

-Me marcho.

—Así está bien.

-Me voy ya.

-Tranquilo, que te vaya bien.

-No pienso volver.

—No importa, si es lo que querés...

—Espero que me perdonés.

-Apurate, te deja el tren.

- Siento que lo estabas esperando.

—No estás del todo bateado.

— ¿Por qué me querés fuera; no podemos hablarlo?

—No, además porque no hay una razón para que estés aquí.

—No sé por qué tanta indiferencia hacia mí.

-No necesitás saberlo, pero si te consuela, yo solo estaba esperando a que te decidieras: ya había hace rato alguien más.

Por fin, Jefrey dejó su pataleta de querer irse sin largarse de una vez por todas, cogió sus cosas y salió dando un portazo. Charly esperó unos minutos para salir de su papel de sufrido-despechado indiferente que en nada le quedaba: no era precisamente a él a quien lo esperaba alguien más. 


\section{Hábitos maternales}

Aunque uno sea un viejo de cuarenta y tantos, hay hábitos cotidianos que no se olvidan o que se quedan invariables en la programación mental que te han hecho. Entré a su habitación por la plancha y, como siempre, mamá dormía a esas horas. No había razón para molestarla, ya ella se había molestado por bastantes años; no obstante, habría preferido haberlo hecho.

Mamá vivió siempre sola conmigo; no sé las causas, ni las he querido preguntar: creo que por mi tata, porque le había puesto los cuernos una y mil veces, o más bien para cuando me tuvo se le acabó el amor para los demás y todos ya la habían dejado sola. "Aquí los hijos no se acuerdan de una, salvo cuando están quebrados y comiendo mierda", era su queja constante contra mis hermanos. Ninguno había vuelto y lo más probable es que no lo haría. Yo los envidiaba, pero nunca se los dije.

Los años de crianza fueron normales, supongo: una madre con una moral férrea, que nunca permitió que se le cuestionara y menos si se trataba de su vida sentimental. "A usted no le importa quién es ese señor", era la respuesta cuando se me ocurría preguntar por alguno de sus amantes. Aprendí mayor a qué venían y por qué mamá no salía casi nunca de casa, salvo para arreglarse, retocarse y estirarse no sé qué.

Ese día entré como siempre a su cuarto, ya los hábitos me guiaban más que la voluntad: entrar sigilosamente, coger la plancha, salir, hacer lo que debía con ella, volver a entrar, dejar el chunche en su sitio y esperar el "¿ya te vas para el trabajo?" de mamá. Yo asentía y le decía hasta luego. La dejaba en su cama, en su casa, en su tiempo consigo misma. Ese día, sin embargo, noté que no se movió.

Salí y entré varias veces. No me atreví a tocarla, ya que las veces que lo había hecho en la vida - dos para ser precisos - mamá había 
tenido un pésimo despertar. Mamá siempre conservó una fuerza poco habitual en una mujer aparentemente delicada. Ese día no ocurrió nada; en un par de días siguientes, la situación fue la misma. Hoy me pregunto por qué mamá lleva varios días sin preguntarme si voy para el brete y no se despierta cuando llego a colocar la plancha en su lugar.

\section{¿Cómo citar este artículo?}

Hernández, R. (Julio-diciembre, 2016). Microrrelatos. Revista humanidades, 6(2), 1-6. doi: dx.doi.org/10.15517/h.v6i2.26750 